\title{
Participatory Communication for Local Government in South Africa: a study of the Kungwini Local Municipality
}

\author{
Futhi Msibi \\ Cecilia Penzhorn
}

\begin{abstract}
Participatory communication, focusing on the active involvement of the people in all stages of development projects, is crucial for sustainable development. South Africa acknowledges the importance of following a participatory communication approach for development, and policies and strategies both on national as well as local government level support this resolve. This article discusses a study which aimed at ascertaining to what extent local government follows accepted participatory communication principles and practices to communicate with the community. The investigation focused on the Kungwini Local Municipality. Interviews with relevant role players were conducted, meetings between the municipality and the community were observed, and documents used by the municipality to communicate with the community were studied. Results indicate that the participatory communication approach is appreciated as being critical for development at local government level and is being successfully applied by the local municipality. Some challenges for further practical implementation of participatory communication were identified, and recommendations for addressing them are offered.
\end{abstract}

Keywords: Participatory Communication; Development Communication; Development; Local Government; Local Municipality

\section{INTRODUCTION}

Issues of sustainable development continue to be of global importance even into the 21st century. Development is regarded as an ethical-political process of social change, and any such change or intervention will implicitly or explicitly have far-reaching consequences on the lives of the people involved in the process (Schoen, 1996: 249; Servaes, 1999: 14). The active participation and involvement of people in decision-making that affects development is therefore central to sustainable development.

Development agencies, practitioners and governments acknowledge that communication is an important mechanism that could bring about effective social change to ensure sustainable development. Communication is fundamentally a social action - the articulation of social relations between people (Servaes, 1999: 13), and one can readily conclude that participation of the people in development initiatives is not possible without communication. True participatory communication can only come about when developmental planners and the people involved work together throughout the decision-making process, when genuine dialogue takes place, and when people are empowered to control the action taken. This process of two-way communication means people's involvement in all stages of a communication development project in order to reach a common goal (Bessette, 2006: 8). 
In South Africa, under the previous dispensation, basic decisions concerning development were made for the people, who became passive receivers of development with no opportunity to identify their needs, act on them and decide on their destiny (Tadesse et al., 2006). The post-apartheid era, however, brought about changes in the South African governance model. The Constitution of the Republic of South Africa (South Africa, 1996) outlines this new approach to an accountable, transparent government, responsive to the needs and development of the people. In line with the Government's goals of democratising development and ensuring that communities actively participate in their own development policies, strategies and mechanisms have also been put in place to support the principles of participatory communication at local government (municipal) level (DPLG, 2005: 11).

This article discusses a project that aimed to investigate the role and the practical application of this participatory communication approach at local government level in South Africa. The study focused on the Kungwini Municipality in Mpumalanga Province, South Africa, where communication practices used by the local municipality to communicate with its communities were evaluated in order to ascertain whether these practices conform to expected and generally acknowledged participatory communication approaches.

\section{PARTICIPATORY DEVELOPMENT COMMUNICATION}

The roots of participatory approaches in development can be traced to the early 1970s when people in the development community started questioning the top-down approaches predominantly used in the 1950s and 1960s (Agunga, 1996: 138; Yoon, 1999). Until that period developed countries were prescribing development whilst providing economic or other assistance (Rahim, 1994: 118), but as a result of concrete experiences of failed projects and policies, they started questioning their own prescriptions. Development had often not bettered conditions for the people - materially, socially or psychologically (Agunga, 1996: 146; Arnst, 1996: 10). In addition, the "driving force of democratisation" (Malan, 1998: 60) contributed to the emergence of concepts such as participation, empowerment and emancipation in the development process. This led to the view that grassroots participation reinforces the chances for communities to adopt development activities appropriate for them.

In the same way as developers, communicators responded to the shift towards participation in development by echoing the new approaches in their work (Yoon, 1999). Participatory communication focuses on people's involvement in all stages of a communication development project, and stands in direct contrast with practices where the emphasis is on projects implemented with outside help and in which the beneficiaries are merely passive receivers of the finished product (Thomas, 1994: 54). This new approach pointed the way to a theory of sharing of information and knowledge, trust, and commitment in development projects. By focusing on participatory involvement of the people, "another world" (Schoen, 1996: 250) is opened in which communities can determine the course of their own lives, concentrating on their unique needs, developing solutions, and making changes of their own choice.

A number of basic principles underlie the concept of participation:

- Power and control. The idea of generative power and control is consistent with and appropriate to the concept of participation (White, 1994: 23). Within the framework of development, participation means the strengthening of the power of the deprived 
majority (Ayee, 1993: 163) and the more equitable sharing of both political and economic power.

- Liberation. As people achieve the ability to determine the course of their own lives, the confidence gained in the process is in itself liberating. Authentic participation leads to a freeing; it is an emancipatory experience (Thomas, 1994: 51).

- Participation as a learning process. Participation can be interpreted as a learning process. People are given the opportunity to set their own goals and take their own decisions, awakening people's latent abilities by offering them choices to enable them to fully develop their potential (Ayee, 1993: 167). Paolo Freire's concept of “conscientisation” - to activate one's consciousness, one's identity, one's talents and one's alternatives - is central to the theme of participation (White, 1994: 24).

- Self-reliance and self-confidence. Participation in and of itself is an act of selfreliance, accompanied by self-confidence (White, 1994: 25). Participation explicitly addresses the aim of developing esteem and self-confidence, providing a context for the recognition of people's knowledge and abilities, and this sense of self-confidence is in itself empowering.

- Knowledge sharing. Knowledge systems and the creation of knowledge have traditionally been the domain of the academic and well-educated (White, 1994: 26), but by setting the stage for dialogue, participation and the use of indigenous knowledge modified this position, and knowledge generation, acquisition and sharing became reciprocal processes.

- Honesty, trust and commitment. Reciprocal collaboration brings about honesty, trust and commitment from both higher-ups as well as grassroots (Servaes, 1996: 17). Participation means to listen what others say, respecting the counterpart's attitude, and having mutual trust.

Although there is general consensus on the principles of participatory development communication and the advantages that this approach has for development projects, in practice the implementation of the concept has proven to be immensely challenging (Yoon, 1997:4).

Some of the main challenges are summarised as follows:

- Allocation of power to the people. In practising the participatory approach, there is equitable sharing of both political and economic power, which often decreases the advantage of certain groups. In many cultures, this runs counter to traditions that recognise the unarguable superiority of the opinion of certain people (Bessette, 2006: 115).

- Shortage of skilled development communication practitioners. The participatory communication approach requires skilled development workers and communicators which often poses a challenge for developing countries. These skills enable the communicator to transfer thoughts, information, feelings and attitudes to consciously ensure that the form in which these ideas are manifested is "decodable" by the partners in the communication process (Yoon, 1997: 14).

- Manipulation of cultural power in society. This refers to the misuse of cultural master codes, often in a biased way. These include literacy, education, elitism, age and technological expertise. Often, communication for development is conveyed by powerful, educated, middle-class men in a written and highly technical format (Malan, 1998: 68). This manipulation has a negative effect and hence disempowers the society for which development is intended. 
- Resource implications. Participation is thought to be "expensive" for the people involved and for the development agencies. Communication support for development initiatives requires financial and material resources and, in many cases, a degree of political will to be able to achieve development objectives (Bessette, 2006: 14).

- Participation takes time and involvement. Participation results are not immediate they take time, commitment and involvement, which can be frustrating for both implementers and the community.

- Top-down communication cannot always be avoided. According to Malan (1998: 182), management should still determine the development agenda, for example, the need for certain major building projects. However, it is imperative that such decisions and processes are clearly communicated to the people involved in the project.

\section{PARTICIPATORY COMMUNICATION IN SOUTH AFRICA}

The development history of South Africa is overshadowed by the apartheid era which reflected an authoritarian style of governance. This approach prevented the majority of South Africans, particularly black people, from the basic right to make decisions, political, social and economical (Tadesse et al., 2006: 20). People and communities were treated as passive recipients of development and had no say in their own development.

With the advent of democracy in 1994 and a new democratic government, a new approach to development was born which was aligned to the principles of democratic governance. New policies, legislation, strategies and plans were initiated to support the improvement of the lives of the poor and the previously disadvantaged. The policies encouraged participation, community empowerment and democratic involvement of communities in the development process (Everett \& Gwagwa, 2005: 4).

In order to enhance these participatory and democratic policies towards development, the South African governance structure has positioned municipalities, also referred to as local government, to drive social development, economic growth and service delivery at a local level.

\section{LOCAL GOVERNMENT IN SOUTH AFRICA}

\section{Introduction}

The current South African governance model defines the country as a unitary state, with a decentralised system of government consisting of three spheres (Open Society Foundation for South Africa, 2006: 145). According to the Constitution of the Republic of South Africa (South Africa, 1996), the government constitutes national, provincial and local spheres of government, which are distinctive, interdependent and interrelated. The Constitution further articulates the roles and responsibilities of the three spheres of government.

The local government sphere, consisting of 284 municipalities, has the responsibility to foster and drive development at local government level. This sphere is often referred to as the "sphere of government that is closest to the people" because of the developmental role that has been given to municipalities (Open Society Foundation for South Africa, 2006:145). The White Paper on Local Government (South Africa, 1998a) states that municipalities must be committed to working with citizens, groups and communities to create sustainable human 
settlements, provide an acceptable quality of life and meet the social, economic and material needs of communities.

\section{Local government and participatory communication}

Neither development communication nor development can exist in a vacuum, and have to be supported by the necessary policies, strategies and plans to ensure that development goals are realised. In principle the South African government, through local government, endorses and acknowledges the importance of communication that is participatory and democratic in nature as an instrument for social change and sustainable development. Following are some of the laws, policies and strategies that have been developed and adopted in this regard:

- Participatory communication is explained in Chapter 7, Section 152 of the Constitution of the Republic of South Africa (South Africa, 1996), which envisages that local government is democratic and accountable to local communities. It further encourages the involvement of communities in the matters of local government.

- These provisions in the Constitution are further supported by Chapter 2, Section 19 of the Local Government Municipal Structures Act (South Africa, 1998b), which requires municipalities to achieve the objectives set out in the Constitution, and also outlines the participatory systems that should exist in municipalities as a platform for addressing the needs of the communities.

- The White Paper on Local Government (1998a), often referred to as the constitution for local government, visualises a process where communities will be involved in governance matters, including planning, implementation and performance monitoring, and review. It states that communities should be empowered to identify their needs, set performance indicators and targets and thereby hold municipalities accountable for their performance in service delivery.

- The Local Government Municipal Systems Act (South Africa, 2000), Chapter 4, calls for municipalities to develop a culture of municipal governance that works hand-inhand with formal representatives of government within a system of participatory governance.

- The Local Government Municipal Finance Management Act (South Africa, 2003) protects and fosters accountability and transparency on municipal finances and spending. The Act outlines ways in which the community can be informed on and involved in the financial issues and budgetary processes of the municipality.

- The Batho Pele White Paper (DPLG, 2005: 15) is the national government's key policy document for transforming public service delivery and is also applicable to the municipal officials. Batho Pele - meaning "People First" - has eight principles that guide government's approach to public service delivery, encourage participation and promote responsive governance.

- The Guidelines for the Establishment and Operation of Municipal Ward Committees provides guidance to municipalities on the establishment of ward committees as a structure responsible for facilitating democracy, participation and structured communication between the municipality and the community (DPLG, 2005:15). 
By implication, the policies and legislative framework as outlined above, place municipalities at the forefront of development in South Africa. They also serve as drivers for democratic, participatory development that involves the participation and involvement of the communities. These principles and policies provided a valid and logical foundation on which the research project described in this article is based.

\section{METHODOLOGY}

\section{Data collection}

A qualitative research approach was followed for this project. By means of a case study, data was collected through interviews, observation and the study of documentary sources in order to investigate the practical implementation of participatory communication in a local municipality.

The Kungwini Local Municipality, chosen for the case study, comprises the town of Bronkhorstspruit and its suburbs as well as the upmarket residential areas of Silver Lakes, Grootfontein and Mooikloof, east of Pretoria. It consists of 27 elected councillors as well as various appointed staff members, and is divided into 14 wards. For the purposes of the study the town and environs of Bronkhorstspruit specifically were targeted. This section of the larger municipality was chosen firstly because it is still a developing municipality which is currently growing at a rapid rate because of its central location between Pretoria, Kempton Park and Witbank. Secondly, because it is a small, semi rural municipality, this makes it accessible in terms of location and culture. Not only do people in smaller towns communicate more freely compared to those in large cities but it is also much easier to get referrals and move around the community as people have time to talk and engage in conversation with strangers.

\section{Interviews}

As the first part of the study aimed to obtain in-depth information regarding the perspectives of the people with regard to the development and communication role of the municipality, survey research by means of semi-structured, face-to-face interviews was identified as the most fitting way in which to accomplish these goals. Using purposive sampling techniques, participants for the interviews were selected from the following five categories:

i) Municipal officials were selected because of their role in implementing the development agenda of the municipality. They have the necessary information regarding the community they serve as well as information on the strategies and policies that guide their development work within the communities.

ii) Ward councillors were selected because of their role as facilitators for development and as such they are custodians of participatory development and communication within the municipality.

iii) Ward committee members. The committees are elected by the community and are representative of all the groups within the community. The committees are chaired by the ward councillor. Ward committees are the main institutionalised structure and channel of communication between communities and the municipality and are often referred to as "the eyes and ears" of the municipality.

iv) Community development workers. These persons are employed civil servants deployed in communities to facilitate the communication between the government, 
local municipalities and the communities. They have vast knowledge and experience on local initiatives as they are members of the communities they serve.

v) Members of the community, those actively participating in development issues as well as those who do not participate, were selected from the different wards of the municipality. As beneficiaries of the development process, community members were considered to be information-rich participants.

In total there were thirty two participants in the study: three municipal officials, four ward councillors, four ward committee members, three community development workers and eighteen community members.

Interview schedules were developed for the face-to-face interviews broadly covering the following aspects: People's beliefs and perspectives about the issues pertaining to the developmental and communication role of the municipality and the community; The involvement of the interviewees in the communication and development processes; Standards of behaviour, that is, what people think should be done to improve the communication processes and systems; and Conscious reasons for actions or feelings, i.e. why people think that doing things in a certain way is desirable or undesirable.

\section{Observation}

Observation was used to supplement information gathered from the interviews. During each observation occasion the researcher took detailed field notes, focusing specifically on the communication practices, participation and communication flow.

Three different interactions between the municipality and the community were observed:

i) The first observation was done during the delivery of the State of the Municipality Address given by the Executive Mayor at the Bronkhorstspruit sports ground on 25 March 2008.

ii) The second observation took place on 3 April 2008 at the Willem Prinsloo Museum in Cullinan, where the municipality delivered the draft municipal budget and the draft IDP (Integrated Development Plan) to the Ward Committees.

iii) The third observation was done on 4 June 2008 at the Masakhane Community Hall in the Kangala Township, where the Ward Committee delivered and discussed the municipal budget and the IDP with the stakeholders of the community.

\section{Documentary sources}

Through the study of various documents used by the municipality to communicate with the community, insight was gained into the nature of the communication practices, as well as the structure and type of information provided to the community. The sources used were the following:

- $\quad$ The municipality's draft Integrated Development Plan (IDP) 2008/09: The IDP is the overall strategic plan of the municipality that also aligns the resources of the municipality with the agreed-on objectives and outcomes.

- Municipal Website: The official website for the municipality that provides information on the structure, mandate and programmes for the municipality.

- Municipal Fact Sheet: This is an information brochure developed by the municipality to provide a summarised version of its composition, structures, services and activities.

- Schedule and minutes of Ward Committee meetings: The schedule and the minutes of the ward meetings are evidence of the execution of the municipal mandate of ensuring consistent communication with the communities relating to their development. 
- $\quad$ The State of the Municipality Address 2008: The State of the Municipality Address is an annual event in which the Executive Mayor reports on the development and financial status of the municipality to the residents and communities within the jurisdiction of the municipality. The event also provides an opportunity for the community to engage and interact with the municipality on issues affecting them.

- Resource Book for Ward Committees: This document provides practical guidance on the functioning of the Ward Committee system. It also provides directions on the concept of public participation in local governance, the establishment of ward committees, roles and responsibilities of ward committees, and their task in the core business of the municipality and the communities they serve.

- The Government Gazette on the Operations of Ward Committees: This government publication provides the legislative guidance on the operation and governance of Ward Committees.

\section{Data analysis}

\section{Analysis of data obtained from the interviews and observations}

The main purpose of data analysis in qualitative research is to organise the information so as to present a narrative that explains the meanings, feelings, opinions and so forth that underlie the behaviour of the participants in the study (Rubin \& Rubin, 1995: 229).

The data from the interviews was documented in the form of extensive notes. Coding principles were implemented to organise the responses into categories that identified and brought together corresponding themes (Berg, 1998: 233; Rubin \& Rubin, 1995: 238). The interview notes were read paragraph by paragraph and word by word, the themes and categories were marked as they appeared, and after a code for each paragraph had been provided, the themes were grouped together.

Thematic coding, developed for "studies in which groups that are studied are derived from the research question and thus defined a priori" (Flick, 1998: 187), was deemed highly suitable for analysing the results obtained from the interviews as well as from the observations.

During each observation occasion the proceedings were observed, informal discussions were held with the participants, and detailed field notes made. As with the interviews, thematic coding was used to analyse this data.

The interviews and observation techniques allowed the researcher to establish a chronological reconstruction of the communication practices, the communication flow, participation, the mechanisms for communication, and the channels used for communication between the municipality and the community.

\section{Analysis of data obtained from documentary sources}

Content analysis was used to analyse data from the documentary sources. Content analysis is a research tool used to determine the presence of certain words or concepts within texts or sets of texts. This includes the literal words in the text being analysed, including the manner in which these words have been offered, "giving the researcher the opportunity to learn about how the subjects or authors view their social worlds” (Berg, 1998: 225). 
The aim of this process of sorting and making sense of data is to provide understanding and explanation from the respondent's perspective. The analysis of the documentary sources in this study provided the researcher with in-depth insight into the nature of the communication relationship between the municipality and the communities, the communication structures, mechanisms, and the type of information that is disseminated to communities

\section{DISCUSSION OF FINDINGS}

A number of principles that serve as guidelines for the practical implementation of participatory communication have been identified, developed and accepted internationally by scholars, researchers and development agencies.

In addition, although the communication channels in participatory communication may be influenced by the many ideological and theoretical approaches that have been identified in the development communication field during the last few decades, communication channels should be in line with the basic principles of the participatory approach and must be sensitive to the needs of the community.

In interpreting the data obtained from the interviews, observation and documentary sources, all of the above was taken into account. In the first place the nature, composition and functions of the communication structures within the Kungwini Municipality were looked at. Secondly the channels used to communicate with the communities were investigated.

The analysis of the data gave a clear picture whether, or to what extent, these practices conform to the basic, acknowledged pre-requisites set for participatory development communication.

\section{Application of participatory communication principles}

\section{Empowerment}

Participatory communication is defined as a process that empowers people to express themselves; giving a voice to the less powerful and allowing the weak and marginalised access to the tools and materials needed to forge their own destinies (Serageldin, 1994: 18). The principle of empowerment thus allows communities to be involved in identifying their development problems, in seeking solutions and taking decisions on how to implement them (Bessette, 2006: 13).

The findings of the study showed that the community is on the whole empowered to make decisions regarding their own development. For example, the IDP (Integrated Development Plan) process, which is undertaken by the municipality annually, allows members of the community through intensive consultation, engagement and communication processes to identify their own problems and to make decisions on priority development issues. It was also clear that the participatory communication and development structures within the municipality are sensitive to the representation of the marginalised in the development process. This is evident from the fact that ward committee and stakeholder forums that exist within the community are representative of groups that include the women's associations, the youth, disabled persons, traditional leaders and many others. 


\section{People-centred approach}

Servaes (1999), supported by various other scholars such as Melkote \& Steeves (2001) and Bessette (2006), maintain that ordinary people should be the "key agents" of social and developmental change. This implies that communication should be viewed as a social activity that is culturally contextual and people-oriented.

The findings indicated that the municipality applies a people-centred approach to facilitate participatory communication. This can be seen in the fact that the IDP engagement and consultation process is driven by the ward committees at community level. The existing stakeholder forums within the community, which are representative of all social groups, are also active in this process indicating the people-centred development process through community-based structures.

Public participation in the municipality has also been embraced as an institutional structure to facilitate participatory communication. One indication of the centrality of people in municipal operations is that the Office of the Speaker and the municipal officials are responsible for ensuring that the engagement process is functional by providing administrative and technical support to ward committees and keeping schedules to track the meetings and engagements with constituencies.

\section{Indigenous knowledge and culture}

Another principle underlying participatory communication relates to recognition of existing indigenous knowledge. Socio-cultural symbolic forms and popular and ethnic culture should all form the basis of dialogue between the communicator and the communities in the communication process (Malan, 1998: 56; Steyn \& Nunes, 2001: 35).

In the Kungwini Municipality the Ward Committee system is placed at the community level and represents the community of which they are part. These committees thus have the same culture and exist under the same conditions as the people they represent. The public participation processes also utilise the existing social structures within the community through the stakeholder forums within each ward that are made up of the different groups of members of the society. These socially oriented and culturally contextual structures ensure that the people are motivated and take pride in their own development.

\section{Communication flow}

A development project that claims to be participatory in nature must ensure that there is twoway communication between the communicator and the receiver in the communication process. Participatory communication advocates a communication process that "allows for knowledge sharing on an equal basis rather than a top-down transmission of information and persuasion” (Melkote, 1991: 270).

The results of this study confirmed that the communication between the councillors and the communities is a two-way process. The councillor and his committee frequently consult with the members of communities, decisions are collectively taken and consensus reached before issues can be presented to council. Important developments and issues are discussed and communicated to all members and there is a common and shared vision on development issues among the community members and the ward committees. 


\section{Participation}

Participation is the core principle underlying participatory communication. The term participatory communication is used to describe “...processes of two-way communication that encourage dialogue centred on problem-analysis; people communicating with one another to search for solutions for their problems...” (Bessette, as quoted in Richardson, 1997).

The results of the interviews, observations and document analysis clearly showed that the people know that it is their democratic and constitutional right to participate in the development process of the municipality. In turn, the municipality is also sensitive and committed to the public participation process and in meeting the expectations of the Constitution and the community with regard to the aim of equal participation for all.

Meetings and scheduled engagements are one of the major participatory methods that are commonly used within the municipality. These are supported by the municipality to ensure that participation takes place in accordance with the public participation guidelines and to ensure that there is equal participation in the development process.

\section{Communication channels used}

\section{Interpersonal channels}

Interpersonal communication channels are highly recommended for participatory communication as they are seen to be localised and intimate in nature. Such channels offer the opportunity to gain knowledge, build understanding, establish identity and appropriately address personal needs (Munyua, 2000; Santucci, 2005: 37) and thus encourage a horizontal process of information exchange, as prescribed by the participatory communication concept.

A number of interpersonal communication channels and methods that are popularly used and that have become traditional ways of communicating with the Kungwini community were revealed. These include: Community meetings - the main communication method used within the municipality; Public/community events that are commonly used to communicate with the people; Izimbizos have been adopted as one of the major participatory communication models of the municipality; Door-to-door campaigns are conducted by Ward Committee members and community development workers on a regular basis to mobilise or inform community members on development issues; and Loudhailers are the most commonly used medium for calling community meetings and communicating messages in the townships.

\section{Mass media}

Santucci (2005: 38) is of the opinion that traditional basic communication methods prescribed by the First World, that is, mass media channels, are not necessarily applicable to the development of Third World countries. The view is that the communication process in development must be led by the needs of the community and not by technology, because the goal is to meet real and accurately defined needs based on the values of all the participants in the communication process.

These opinions were to some extent substantiated by the findings of the study which showed that mass media methods are not necessarily the channels of choice or most commonly used communication channels in the Kungwini Municipality. 
However, radio in the form of the local community station, the Kangala community radio, was regarded as an accessible and effective communication media because of its huge listenership and because it uses the local language. The SABC radio stations, namely Ikwekwezi (Ndebele) and Thobela Fm (Sepedi), are used when there is a need to communicate messages and interviews with the municipal authorities. National newspapers are mainly used for advertising tenders and similar announcements by the municipality. The municipal website was another communication channel that has recently been developed by the municipality. It was indicated that television is not used as a medium for communicating because it is too expensive.

\section{Preferred communication channels and methods}

With the aim of ascertaining which channels would appeal to the people and could assist them in participating effectively in the development process of the municipality, interviewees were asked about the types of communication channels that are preferred by the community.

- Ninety-five percent of the respondents from the community, the municipality and the councillors were of the opinion that the Kangala local community radio station should be used more effectively as a communication platform. They said that the use of the radio should not just be limited to announcements as was currently the case, because it has great potential to educate, empower and motivate people towards effective participation in development processes.

- Eighty percent of the respondents indicated that cell phones are a very popular gadget in the communities and might therefore be an appropriate communication channel for development messages.

- Seventy percent of the respondents were of the opinion that there is a need for a newspaper that is owned by the municipality. The view was that this newspaper would be able to communicate development issues and the people would be able to contribute articles on their expectations and experiences and thus enhance development in the area.

- Forty percent of the respondents suggested that mobile municipal offices can help to reach out to people in excluded areas such as rural areas. This, they said, would give these people access to municipal services and development would be brought closer to them.

- Thirty percent of the respondents from the community are of the view that MultiPurpose Community Centres, now called Thusong Service Centres, are an effective way to communicate with people. Although the respondents do not at this stage have access to such a centre, they were of the opinion that in municipal areas where there are such centres, people have more access to development and other government services. ${ }^{1}$

- Ten percent of the respondents suggested that water and electricity bills might be a good communication channel if they were to be utilised. However, they did mention that this method is only applicable to the community members who reside in the suburbs because they receive bills. Most of the other community members living in outlaying areas or townships use the pay-as-you-go electricity option and therefore do not receive bills.

- Five percent of the respondents indicated that satellite municipal offices based in the townships and settlements have the potential to improve the communication system

\footnotetext{
${ }^{1}$ Thusong Service Centres were initiated in 1999 as "a primary vehicle for the implementation of development communication and information to the people” (Thusong Service Centre, 2010)
} 
and service delivery for the municipality because they would be accessible to the people, considering the extended area that the municipality serves.

\section{CHALLENGES AND RECOMMENDATIONS}

The results of this study clearly indicate that that the participatory approach and the role of effective communication are acknowledged and appreciated at local government level as being critical for facilitating, enhancing and driving development. However, some shortcomings and resulting challenges for the practical implementation of participatory communication at the Kungwini Municipality were identified:

- The municipality does not have development communication practitioners. The communications department of the municipality has a communications manager who is mainly responsible for corporate communications and not necessarily development communication. Also the officials in the Office of the Speaker, which drives the public participation process, are coordinators of the public participation process but are unable to facilitate or manage the communication process. In essence, skills in development communication as an area of expertise do not exist within the municipality.

- In the implementation of development communication within the municipality, finance issues are one of the major challenges. The budget allocated for communications within the municipality cannot cater for major communication activities such as translations, staff, publications and other pertinent communication resources and processes

- In the same vein, the community representatives responsible for facilitating community engagements at times lack motivation because they are not compensated for the community work which can be very demanding. This affects the effectiveness of the committees and the engagement with community members.

- The communities are involved in and consulted extensively on the identification and prioritisation of the development initiatives but they are not always empowered to take full responsibility for driving the development process and the evaluation of the development. This leads to mistrust between the community and the municipality as the community is often not satisfied with the manner in which the identified projects are implemented.

- The study also showed that a country like South Africa is a deeply divided society on a range of fronts, of which class, level of urbanisation, race, ethnicity and language divisions are only a few of the social and demographic factors with which government, and in this case local government, has to contend with. This poses a challenge for the implementation of participatory communication at municipal level where all these communities within the same society have different communication and development needs.

- Another issue that has emerged is that communication alone is not the solution to development issues. It is clear from the study that the development problems and issues that arise emanate not only from communication problems but also relate to other institutional arrangements, resource issues, and the relationship between the three spheres of government (national, provincial and local government). This indicates that communication support in development should be addressed holistically to ensure that other issues that may affect the development process are also considered. 
It is recommended that some of the problems be solved as follows:

The ward committees, municipal officials working with communities, and the community representatives, should be trained in participatory communication. This would enable each of these development partners to provide the necessary and appropriate support for the development communication process.

The ward committees need to be provided with incentives, perhaps in the form of monetary compensation, to increase their commitment to the development communication initiatives undertaken by the municipality. Their responsibility in the development process is very demanding and should not be limited to volunteering.

Programmes to enable/empower the community, especially the traditionally marginalised groups such as women, must be undertaken so that they are able to make a meaningful contribution to the development processes of the municipality. This will contribute towards breaking down the cultural barriers preventing them from active participation in the development process.

There is a need for a definitive development communication strategy, developed in partnership with the people from the various communities. Such a strategy would be able to clearly identify messengers and messages for development, identify appropriate communication methods and channels, and communicate the successes of as well as the problem associated with the development processes so that the people can appreciate that they are part of the process. Such a communication strategy would also serve to support the public participation process, the ward committees and the local communication structures. This would ensure that communication for development is inclusive and comprehensive and thus empower the whole community to make meaningful contributions to the development process.

It is also important that the municipality adapt the communication methods and channels such as more extensive use of radio, a municipal newsletter, municipal newspaper, cell phones and other methods that have been suggested by the people, in order to improve the communication process.

One of the most obvious of these methods, as pointed out by the respondents, are Thusong Service Centres. The original aim of these centres, i.e. the original Multi Purpose Community Centres, was to form the backbone of development communication and the dissemination of information in municipalities (Snyman \& Snyman, 2003: 97). The roll-out, funding and monitoring of Thusong Service Centres are integral to municipal Integrated Development Plans (Thusong Service Centre, 2010) and the establishment of one in the Kungwini Municipality should be investigated.

\section{IN CONCLUSION}

The aim of this project was to investigate the application of participatory communication initiatives being undertaken and implemented on local government level in South Africa. The Kungwini Municipality was used as a case study for the investigation. Results of the study showed that communication and specifically participatory communication plays a significant role in local government development initiatives. This communication ensures that communities are part of the development process and that the needs, expectations and 
implementation of the development initiatives are inclusive and driven by the people who will benefit from them.

Although this investigation relates specifically to the Kungwini Municipality, the results and suggestions could be of value for other municipalities as well. It is suggested that further research on this important communication issue be conducted in other municipalities in the country. This would serve as a means of developing appropriate practical and creative methods for participatory communication applicable within the general South African context, and thereby improve the development communication practices in the sphere of local government in order to meet their developmental mandate.

\section{References}

Agunga, R.A. 1996. Developing the Third World: a communication approach. Commack, N.Y.: Nova Science.

Arnst, R. 1996. Participatory approaches to the research process. In: Servaes, J., Jacobson, T.L., \& White, S.A. eds. Participatory communication for social change. New Delhi: Sage: 109-126.

Ayee, E.S.A. 1993. A participatory communication approach to rural community development. D.Phil-dissertation. Potchefstroom: Potchefstroom University for Christian Higher Education.

Bessette, G. 2006. ed. People, land and water: participatory development communication for natural resource management. S.l.: International Development Research Centre.

Berg, B.L. 1998. Qualitative research methods for the social sciences. 3rd ed. Boston, Mass.: Allyn \& Bacon.

DPLG (Department of Provincial and Local Government). 2005. Ward Committee resource book: best practices and lessons learnt for municipal officials, councillors and local governance practitioners. Pretoria: Department of Provincial and Local Government.

Everett, D. \& Gwagwa, L. 2005. Community driven development in South Africa, 1990-2004. Africa Region working paper, series No. 92. World Bank. [Online]. Available: http://www.worldbank.org/afr/wps/index.htm.

Flick, U. 1998. An introduction to qualitative research. London: Sage.

Malan, C.1998. Development communication as part of culture. Communicare, 17(1): 160-185.

Melkote, S.R. 1991. Communication for development in the Third World: theory and practice. New Delhi: Sage.

Melkote, S.R. \& Steeves, H.L. 2001. Communication for development in the Third World: theory and practice for empowerment. .2nd ed. Thousand Oaks, CA.: Sage.

Munyua, H. 2000. The role of information and communication technologies in rural development and food security: lessons from field experiences in developing countries. [Online] Available: http://www.fao.org/sd/Cddirect/Cdre0055b.htm. 
Open Society Foundation of South Africa. 2006. South Africa: democracy and participation. London: AfriMap.

Rahim, S.A. 1994. Participatory development communication as a dialogical process. In: White, S.A., Nair, K.S. \& Ascroft, J. eds. Participatory communication: working for change and development. New Delhi: Sage: 117-137.

Richardson, D. 1997. The sustainability of participatory communication. (ParCom 97). [Online]. Available: http://www.panasia.org.sg/ius/conf/.

Rubin, H.J. \& Rubin, I.S. 1995. Qualitative interviewing: the art of hearing data. Thousand Oaks, CA.: Sage.

Schoen, R-J. 1996. Fitting projects to people or people to projects? In: Servaes, J., Jacobson, T.L. \& White, S.A. eds. Participatory communication for social change. New Delhi: Sage: 249-266.

Santucci, F.M. 2005. Strategic communication for rural development. [Online]. Available: http//siteresources.worldbank.org/EXTDEVCOMMENG/Resources/Strategiccommruralfinal.pdf.

Serageldin, I. 1994. Water supply and environmental sustainability: the financing challenge. Washington, DC: World Bank.

Servaes, J. 1996. Introduction: participatory communication and research in development settings. In: Servaes, J., Jacobson, T.L. \& White, S.A. eds. Participatory communication for social change. New Delhi: Sage: 13-27.

Servaes, J. 1999. Communication for development: one world, multiple cultures. Cresskill, NJ: Hampton Press.

Snyman, M. \& Snyman, R. 2003. Getting information to disadvantaged rural communities. South African Journal of Library and Information Science, 69(2): 95-107.

South Africa. 1996. Constitution of the Republic of South Africa. Pretoria: Government Printer.

South Africa. 1998a. White Paper on Local Government. Pretoria: Government Printer.

South Africa. 1998b. Local Government: Municipal Structures Act, no. 117 of 1998. Pretoria: Government Printer.

South Africa. 2000. Local Government: Municipal Systems Act, no. 32 of 2000. Pretoria: Government Printer.

South Africa. 2003. Local Government: Municipal Finance Management Act, no. 56 of 2003. Pretoria: Government Printer.

Steyn, B \& Nunes, M. 2001. Communication strategy for community development: a case study of the Heifer project. Communicatio, 27 (2): 29-48.

Tadesse, E.. et al. 2006. The people shall govern: a research report on public participation in policy processes. Johannesburg: Centre for the Study of Violence and Reconciliation (CSVR) and Action for Conflict Transformation (ACTION). 
Thomas, P. 1994. Participatory development communication: philosophical premises. In: White, S.A., Nair, K.S. \& Ascroft, J. eds. Participatory communication: working for change and development. New Delhi: Sage: 49-59.

Thusong Service Centre. 2010. Home page. [Online]. Available: http://www.thusong.gov.za.

White, S.A. 1994. Introduction. The concept of participation: transforming rhetoric to reality. In. White, S.A., Nair, K.S. \& Ascroft, J. eds. Participatory communication: working for change and development. New Delhi: Sage: 15-33.

Yoon, C.S. 1997. Participatory communication for development. [Online]. Available: http://www.southbound.com.my/communication/parcom.htm. 